\title{
Vasa Vasora in the Tunica Media of Goat Aorta
}

\author{
Vasa Vasora en la Túnica Media de la Aorta de Cabra
}

Julius A. Ogeng'o; Phillip M. Mwachaka \& Beda O. Olabu

OGENG'O, J. A.; MWACHAKA, P. M. \& OLABU, B. O. Vasa vasora in the tunica media of goat aorta. Int. J. Morphol., 29(3):702$705,2011$.

SUMMARY: This study aimed at describing the distribution of vasa vasora in the tunica media of various parts of goat aorta, since this influences the physico-mechanical properties and disease occurrence. Specimens were obtained from ascending, arch, each vertebral level of descending thoracic and various segments of abdominal aorta of sixteen healthy adult male domestic goats (Capra hircus). They were fixed in $10 \%$ formaldehyde solution, and routinely processed for paraffin embedding. Seven micron thick sections were stained with Mason's Trichrome stain. Vasa vasora are present in the tunica media of all the aortic segments. In the proximal segments, they co-localize with muscle islands found in the adventitial half. Their density declines caudally, but they are still present in the tunica media even in the abdominal aorta where the thickness is less than $0.5 \mathrm{~mm}$ and elastic lamellae less than 29. Vasa vasora in the goat aortic tunica media penetrate into the luminal half and are present even in relatively thin segments. This extent, which may enhance vascular health, suggests that the goat aortic wall is very active, a feature probably related to auxillary pump function of the muscle islands in the aortic wall.

\section{KEY WORDS: Vasa vasora; Aorta; Goat.}

\section{INTRODUCTION}

Vasa vasora, small nourishing channels found within the walls of larger vessels are important in the structural and functional integrity of the aorta (Heistad \& Marcus 1978; Stefanadis et al., 1995; Angouras et al., 2000). Their extent and density in the vascular wall are influenced by its thickness and may vary with animal species (Wolinsky \& Glagov, 1967; Stefanadis et al., 1995; Angouras et al.). They play an important role in aortic diseases such as aortoarteritis (Sethi et al., 1989), atherosclerosis (Goertz et al., 2007; Ritman et \& Lerman, 2007) and aneurysm (Mulaidzi, 2009). Further, they may also be a target for therapeutic intervention in these diseases (Langheinrich et al., 2007). Since the goat is a suitable model for studying vascular disease (Lemson $e t$ al., 1999) the distribution of vasa vasora in the tunica media of its aorta was studied by light microscopy.

\section{MATERIAL AND METHOD}

Aortae for this study were obtained from 16 male healthy domestic goats (Capra hircus) aged between 6 and 24 months and weighing $10-60 \mathrm{~kg}$, purchased from private livestock farmers in the outskirts of Nairobi. The animals were weighed then euthanised with an overdose of sodium pentabarbitone $20 \mathrm{mg} / \mathrm{ml}$ injected intravenously. The abdomen and thorax were opened by midline incisions, and the pericardium slit to expose the heart. To clear off blood, normal saline was introduced through the left ventricle and drained out through the right auricle. By the same means, the animal was fixed by gravimetric perfusion using $10 \%$ formaldehyde solution. Specimens taken from ascending, arch, each vertebral level of thoracic, pre-renal, renal and post renal segments were processed routinely for paraffin embedding and $7 \mu \mathrm{m}$ sections stained with Masson's trichrome stain to demonstrate smooth muscle cells, collagen and blood vessels. The sections were examined by Leica $\subseteq$ microscope at various magnifications. Vasa vasora were identified as vessels within the tunica media and their arrangement and extent of penetration studied. Representative micrographs of these vasa were taken.

\section{RESULTS}

The aortic wall comprises three layers namely tunica intima, media and adventitia. Tunica media comprise regular concentric elastic lamellae which decline in number caudally. In the ascending, arch and proximal thoracic down to $\mathrm{T} 10$, the lamellae of the adventitial side are interrupted 

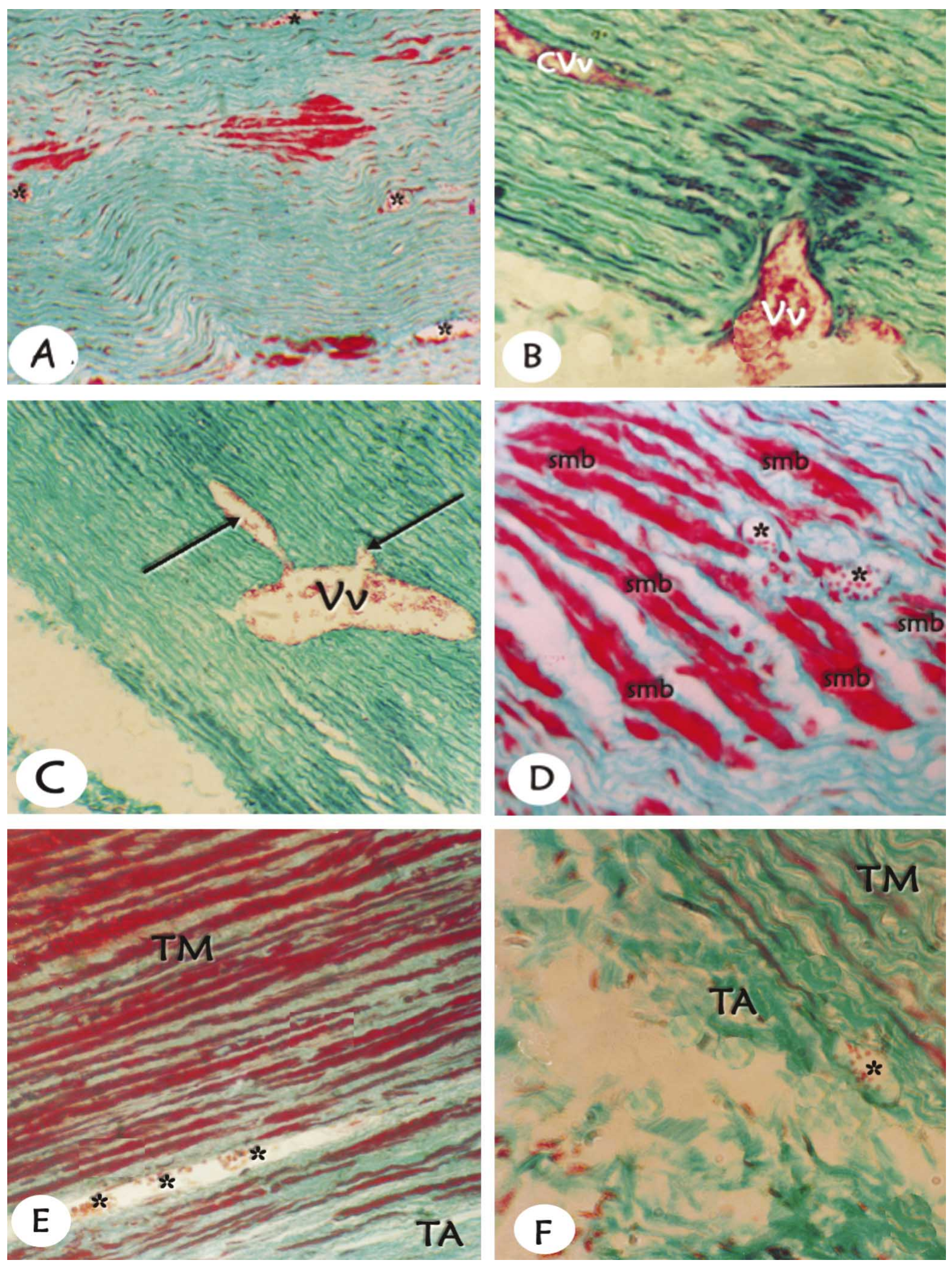

Figs. 1A-F: Vasa vasora in the tunica media of the goat aorta. A.Vasa vasora (stars) in the luminal half of the tunica media of ascending aorta. $\mathrm{x} 100$; B. Vasa vasorum (vv) projecting into the tunica media of aortic arch at right angles with a sleeve of connective tissue. Note a circumferential branch (cvv) between the lamellae. x250; C: A perpendicular vasa vasorum (vv) in the thoracic aorta and its branches (arrows) running circumferentially. x100. D. Vasa vasora (stars) co-localized with muscle island in which they are surrounded by smooth muscle bundles (smb). x250; E. Vasa vasora (stars) in the outer one third of the tunica media (TM) adjacent to the tunica adventitia (TA). Of distal thoracic x250; F. Vasa vasorum (star) between Tunica media (TM) and tunica adventitia (TA) of abdominal aorta 250. 
by interlocked muscle nests which form islands. Vasa vasora extend into tunica media from the tunica adventitia and penetrate into the inner half of the proximal parts of the aorta (Fig. 1A, B). The vessels penetrate the media perpendicular to the long axis accompanied with a sleeve of connective tissue, then branch and ramify between the elastic lamellae (Fig. 1 B, C). Frequently, in the proximal segments these vessels co-localize with muscle islands which exist in the adventitial half of the tunica media (Fig. 1D). In the distal segments, of the thoracic and in the abdominal aorta, vasa vasora are still present in the tunica media, but are confined to the outer one third of the tunica media, or the media-adventitial border (Fig. 1E,F).

\section{DISCUSSION}

In the ascending aorta, aortic arch, and proximal descending thoracic aorta, vasa vasora extend into the inner half of the tunica media. This is concordant with literature reports that vasa vasora are present in the tunica media close to the intima, in the horse (Woodruff, 1926), cow (Knieriem, 1967), sheep (Song et al., 1985), monkey (Heistad \& Amstrong, 1986), dog (Stefanadis et al., 1993), and pig (Angouras et al.). These medial vasa vasora, considered to be more effective than adventitial ones (Webster \& Heistad, 1985), supply a specific part of the aortic media since their removal causes medial necrosis (William et al., 1988, Angouras et al.). The type and density of vasa vasora are influenced by wall thickness (Kachlick et al., 2002) oxygen content of luminal blood (Heistad et al., 1981) and activeness of the vascular wall in regulating the amount of blood flow to organs (Chuncher \& Somana, 2005). Their penetration into the tunica media is therefore consistent with wall thickness exceeding $0.5 \mathrm{~mm}$ and number of lamellae. It suggests that the aorta is active in pumping blood.

The vasa vasora of the goat proximal aorta in many places co-exist with the muscle islands in the adventitial half of the tunica media. This co-existence may be designed to enable the vasa vasora deliver nutrients, thus supporting contractile activity of smooth muscle cells. This is supported by studies which suggested that the activeness of the vascular wall in varying the amount of blood flow to certain organs may be an important factor in the existence, density and distribution of the vasa vasora (Chuncher $\&$ Somana).

In the distal thoracic and abdominal aorta, the vasa vasora extend into the outer zone of the tunica media. This is at variance with reports that there are no vasa vasora in the abdominal aorta (Ramsey, 1936; Geiringer, 1951; Wolinsky \& Glagov, 1969; Heistad et al., 1978). According to these authors, vasa vasora only penetrate the tunica media where the lamellae are more than 29 , and wall thickness exceeds $0.5 \mathrm{~mm}$. The presence of vasa vasora in the tunica media even where the wall thickness is less than $0.5 \mathrm{~mm}$, and there are less than 29 lamellar units suggests that the abdominal aorta in goat is more active than hitherto perceived. Further, that other factors are important in determining the density and penetration of vasa vasora. Such factors may include the activeness of the vessel wall in regulating blood flow (Chuncher \& Somana); and metabolic activity (Kachlick et al., 2007). The overall cellularity and activity of the cells in other functions of the vessel wall such as remodeling, mechanical strength and immune surveillance, may also be important.

In conclusion, vasa vasora in the goat aortic tunica media penetrate into the luminal half and are present even in relatively thin segments. This extent, which may enhance vascular health, suggests that the goat aortic wall is very active, a feature probably related to auxillary pump function of the muscle islands in the aortic wall.

ACKNOWLEDGEMENTS. We are grateful to L. K. Wainaina; M. N. Kibiru, \& C. Kamwaro for technical assistance and Catherine Chinga for typing the manuscript.

OGENG'O, J. A.; MWACHAKA, M. \& OLABU, B. O. Vasa vasora en la túnica media de la aorta de cabra. Int. J. Morphol., 29(3):702-705, 2011.

RESUMEN: El objetivo de este estudio fue describir la distribución de vasa vasora en la túnica media de diversas partes de la aorta de cabra, ya que esto influye en las propiedades físicas y la aparición de enfermedades. Las muestras se obtuvieron de 16 cabras machos adultos sanos (Capra hircus) desde la porción ascendente del arco aórtico, segmentos torácicos descendentes y de la parte abdominal de la aorta. Las muestras se fijaron en solución de formol al 10\%, y fueron sometidas a procesamiento de rutina para inclusión en parafina. Secciones de siete micras de grosor se tiñeron con reacción tricrómica de Masson. Vasa vasora están presentes en la túnica media de todos los segmentos de la aorta. En los segmentos proximales, que localizan con islas de músculo que se encuentra en la mitad de la adventicia. Su densidad disminuye en sentido caudal, pero aún están presentes en la túnica media, incluso en la parte abdominal de la aorta, donde el espesor es inferior a 0,5 mm y láminas elásticas menos de 29. Vasa vasora en la túnica media de la aorta de la cabra penetran en el medio luminal y están presentes incluso en segmentos relativamente delgados. Esta medida, que puede mejorar la salud vascular, sugiere que la pared aórtica de la cabra es muy activa, una característica probablemente relacionada con la función de la bomba auxiliar de las islas del músculo en la pared aórtica.

PALABRAS CLAVE: Vasa vasora; Aorta; Cabra. 


\section{REFERENCES}

Angouras, D.; Sokolis, D. P.; Dosios, T.; Kostomitsopoulus, P. N.; Boudoulas, H.; Skalkeas, G. \& Karayannacos, P. E. Effect of impaired vasa vasorum flow on the structure and mechanics of the thoracic aorta: implications for the pathogenesis of aortic dissection. Eur. J. Cardiothorac. Surg., 17(4):468-73, 2000.

Chuncher, S. \& Somana, R. Types of vascular wall as related to vasa vasorum in common tree shrew (Tupaia glis). Microsc. Res. Tech., 67(6):317-24, 2005

Geiringer, E. Intimal vascularization and atheromatosis. $J$. Pathol. Bacteriol., 63:201-11, 1951.

Goertz, D. E.; Frijlink, M. E.; Krams, R.; de Jong, N. \& van der Steen, A. F. W. Vasa vasorum and molecular imaging of atherosclerotic plaques using non linear contrast intravascular ultrasound. Neth. Heart J., 15(2):77-80, 2007.

Heistad, D. D. \& Armstrong, M. L. Blood flow through vasa vasorum of coronary arteries in atherosclerosis in monkeys. Arteriosclerosis, 6(3):326-31, 1986.

Heistad, D. D.; Marcus, M. L.; Law, E. G.; Armstrong, M. L.; Ehrhardt, J. C. \& Abbound, F. M. Regulation of blood flow to the aortic media in dogs. J. Clin. Invest., 62:133-140, 1978.

Heistad, D. D.; Marcus, M. L.; Larsen, G, E. \& Armstrong, M. L. Role of vasa vasorum in nourishment of the aortic wall. Am. J. Physiol., 240:H781-H787, 1981.

Kachlick, D.; Baca, V.; Stingl, J.; Sosna, B.; Lametschwandtner, A.; Minnich, B. \& Setina, M. Architectonic arrangement of the vasa vasorum of the Human Great Saphenous vein. $J$. Vasc. Res., 44:157-68, 2007.

Knieriem, H. J. Electron microscopic study of bovine ateriosclerotic lesions. Am. J. Pathol., 50(6):1053-65, 1967.

Mulaudzi, T. V. HIV associated vasculopathy. CME, 27(7):32022, 2009.

Langreinrich, A. C.; Kampschulte, M.; Buch, T. \& Bohle, R. M. Vasa vasorum and atherosclerosis - Quid Novi? Thromb. Haemost., 97(6):873-9, 2007.

Lemson, M. S., Daemen, M. J.; Kitshaar, P. J. \& Tordoir, J. H. A new animal model to study intimal Hyperplasia in Av fistula. J. Surg. Res., 85(1):51-8, 1999.

Ramsey, E. M. Nutrition of the blood vessel wall: review of the literature. Yale J. Biol. Med., 9:13-36, 1936.
Ritman, E. L. \& Lerman, A. Role of vasa vasorum in Arterial disease: A emerging factor. Current. Cardiol. Rev., 3(1): 4355, 2007.

Sethi, R.; Kumar, R.; Vaidya, M. C. \& Chopra, P. Histopathological evaluation of experimentally induced aortoarteritis. J. Anat. Soc. India, 38(2):87-95, 1989.

Song, S. H.; Kratky, R. G. \& Roach, M. R. Scanning electron microscopic studies of the vasa vasorum of thoracic aortas. Acta Anat., 122:133-7, 1985.

Stefanadis, C. I.; Karayannacos, P. E.; Boudoulas, H. K.; Stratos, C. G., Vlachopoulos, C. V.; Dontas, I. A. \& Toutouzas, P. K. Medial necrosis and acute alterations in aortic distensibility following removal of vasa vasorum of canine ascending aorta. Cardiovasc. Res., 27(6):951-6, 1993.

Stefanadis, C.; Vlachopoulos, C.; Karayannacos, P.; Boudoulas, H.; Stratos, C.; Filippides, T.; Agapitos, M. \& Toutouzas, P. Effect of vasa vasorum flow on structure and function of the aorta in experimental animals. Circulation, 91(10):2669$78,1995$.

Werber, A. H. \& Heistad, D. D. Diffusional support of arteries. Am. J Physiol., 248:H901-6, 1985.

William, J. K.; Armstrong, M. L. \& Heistad, D. D. Blood flow through new microvessels: factors that affect regrowth of vasa vasorum. Am. J. Physiol. Heart Circ. Physiol., 254:H126-H32, 1988.

Wolinsky, H. \& Glagov, S. Nature of species differences in the medial distribution of aotic vasa vasorum in mammals. Circ. Res., 20:409-21, 1967.

Wolinsky, H. \& Glagov, S. Comparison of abdominal and thoracic aortic medial structure in mammals. Deviation of man from the usual pattern. Circ. Res., 25:677-86, 1969.

Woodruff, C. E. Studies on the vasa vasorum. Am. J. Pathol., 2:567-69, 1926.

Correspondence to:

Julius A. Ogeng'o

Department of Human Anatomy

University of Nairobi

P. O. Box $30197-00100$

Nairobi

KENYA

E-mail: jogengo@uonbi.ac.ke

Received: 16-02-2011

Accepted: 24-05-2011 